\title{
APPARENT DIGESTIBILITY OF DIETS WITH COMBINATIONS OF SOYBEAN HULLS AND COASTCROSS (Cynodon sp.) HAY OFFERED TO RAM LAMBS
}

\author{
Rafael Canonenco de Araujo ${ }^{1}$; Alexandre Vaz Pires ${ }^{2 *}$; Ivanete Susin²; Fumi Shibata Urano ${ }^{1}$; \\ Clayton Quirino Mendes ${ }^{1}$; Gustavo Henrique Rodrigues ${ }^{1}$; Irineu Umberto Packer ${ }^{2}$ \\ ${ }^{1}$ USP/ESALQ - Programa de Pós-Graduação em Ciência Animal e Pastagens. \\ ${ }^{2}$ USP/ESALQ - Depto. de Zootecnia, C.P. 09 - 13418-900, Piracicaba, São Paulo - Brasil. \\ *Corresponding author <alvpires@esalq.usp.br>
}

ABSTRACT: Soybean hulls (SH) are an alternative fiber source that may be used to maintain neutral detergent fiber (NDF) concentration while increasing the energy concentration of ruminant diets. The objective of this experiment was to determine the effects of replacing coastcross (Cynodon sp.) hay NDF by SH NDF on the apparent digestibility of nutrients and nitrogen balance of Santa Inês ram lambs. Twenty-four animals $(42.5 \pm 3.6 \mathrm{~kg}$ of body weight and six months old) were placed in metabolism crates and assigned in a randomized complete block design defined by body weight (BW). Experimental diets provided a similar concentration of NDF (52\%) and crude protein (15\%). Hay NDF from a $70 \%$ roughage-based diet was replaced with SH NDF by 33\%, 67\%, and 100\%, resulting in $0,25,52$, and $77 \%$ of SH in the dietary dry matter (DM), respectively. There was a linear increase $(p<0.01)$ on dry matter and organic matter (OM) intakes expressed as $\mathrm{kg}^{-1} \mathrm{day}^{-1}$ and \% of BW, with $\mathrm{SH}$ inclusion. The OM digestibility showed a quadratic effect $(p<0.05)$ with $\mathrm{SH}$ inclusion while crude protein digestibility showed a linear decrease $(p<0.0001)$. A quadratic effect was also observed for NDF $(p<0.05)$ and acid detergent fiber $(p<0.01)$ digestibilities. The $\mathrm{N}$ retentions, as $\%$ of $\mathrm{N}$ consumed and $\%$ of $\mathrm{N}$ absorbed, resulted in quadratic effects $(p<0.05)$ with SH addition. There was no effect $(p>0.05)$ on water intake when SH replaced hay. The SH can replace forage and may be included up to $77 \%$ in the dietary DM of ram lambs with satisfactory values of nutrient digestibilities.

Key words: NDF, hair sheep, nitrogen balance, Santa Inês, water intake

\section{DIGESTIBILIDADEAPARENTE DE DIETAS COM COMBINAÇÕES DE CASCA DE SOJA E FENO DE “COASTCROSS” (Cynodon sp.) OFERECIDAS PARA CORDEIROS}

\begin{abstract}
RESUMO: A casca de soja (CS) é uma fonte de fibra alternativa que visa manter o teor de fibra em detergente neutro (FDN) e aumentar a concentração energética da dieta de ruminantes. O objetivo deste experimento foi avaliar os efeitos da substituição da FDN de feno de "coastcross" (Cynodon sp.) pela FDN da CS sobre a digestibilidade aparente dos nutrientes e balanço de nitrogênio em cordeiros Santa Inês. Vinte e quatro animais $(42,5 \pm 3,6 \mathrm{~kg}$ de peso vivo e seis meses de idade) foram colocados em gaiolas para ensaio de digestibilidade e arranjados em delineamento blocos completos casualizados definidos pelo peso vivo (PV). As dietas isonitrogenadas (15\% de proteína bruta) continham concentrações semelhantes de FDN (52\%). O tratamento controle foi composto de $70 \%$ de feno na matéria seca (MS) da dieta, sendo a FDN proveniente do feno substituída em 33\%, 67\% e 100\% pela FDN proveniente da CS, correspondendo a $0,25,52$ e $77 \%$ de CS na MS da dieta de cada tratamento, respectivamente. Houve aumento linear $(p<0,01)$ no consumo de matéria seca e consumo de matéria orgânica (MO) nas unidades $\mathrm{kg} \mathrm{dia}^{-1} \mathrm{e} \%$ do PV com a inclusão da CS. A digestibilidade da MO apresentou efeito quadrático $(p<0,05)$ com a inclusão de CS, enquanto a digestibilidade da proteína bruta apresentou decréscimo linear ( $p<0,0001)$. Efeito quadrático foi também observado nas digestibilidades da $\operatorname{FDN}(p<0,05)$ e da fibra em detergente ácido $(p<0,01)$. As retenções de $\mathrm{N}$, em $\%$ do $\mathrm{N}$ consumido e \% do $\mathrm{N}$ absorvido, apresentaram resposta quadrática $(p<0,05)$ com a adição de CS. Não houve efeito $(p>0,05)$ da inclusão de CS sobre o consumo de água. A CS pode substituir forragem e ser incluída em até 77\% na MS da dieta de cordeiros, apresentando valores satisfatórios de digestibilidade dos nutrientes.

Palavras-chave: FDN, balanço de nitrogênio, consumo de água, ovino deslanado, Santa Inês
\end{abstract}




\section{INTRODUCTION}

Soybean hulls may replace forage in ruminant diets due to their high fiber concentration, $60.3 \%$ of neutral detergent fiber (NDF), $44.6 \%$ of acid detergent fiber (ADF), and $2.5 \%$ lignin (NRC, 2001). In vitro studies have showed dry matter (DM) digestibilities of 95\% (Hall et al., 1998) and $88 \%$ (Miron et al., 2001) for SH. However, high inclusions of SH may result in lower in vivo DM digestibilities than expected, for example 58\% (Quicke et al., 1959) and 63.9\% (Berge \& Dulphy, 1991) have been observed in sheep. These low values generally occur because $\mathrm{SH}$ have a high passage rate from the rumen (Nakamura \& Owen, 1989), explained by their small particle size (Mertens, 1997) and high specific gravity (Weidner \& Grant, 1994a; Bhatti \& Firkins, 1995).

Santa Inês lambs have a lower growth potential than meat type wool lambs (Figueiredo et al., 1990), presenting average daily gains of $227 \mathrm{~g} \mathrm{~d}^{-1}$ (Rocha et al., 2004) and $277 \mathrm{~g} \mathrm{~d}^{-1}$ (Urano et al., 2006) when receiving high-grain diets. For this reason, even high inclusions of SH may be adequate for the growth of Santa Inês lambs. However, to recommend this practice the nutrient utilization efficiencies must be determined.

The association of a forage source (long particle fiber) with SH may increase the rumen mat (Weidner \& Grant, 1994b) reducing the SH passage from the rumen. Most studies with SH replacing forage show differences in NDF concentration among treatments because NDF concentration in SH is not the same than in forages. An improvement in DM digestibility is expected with SH inclusion but a minimum amount of long particle forage is also supposed to be necessary to maximize rumen degradation. In this particular experiment, coastcross hay was used as a reference roughage type.

Utilizing SH as a roughage replacer, the objective of this experiment was to determine the combination of $\mathrm{SH}$ and hay that maximizes apparent digestibilities of nutrients, and evaluate the effects of replacing coastcross hay NDF by SH NDF on nutrient and water intakes, and also on $\mathrm{N}$ balance of Santa Inês ram lambs.

\section{MATERIAL AND METHODS}

\section{Animals, diets, and sampling procedures}

This experiment was conducted from May to June 2005 in Piracicaba (22 $42^{\prime}$ S and $47^{\circ} 38^{\prime}$ W), State of São Paulo, Brazil. Twenty-four Santa Inês ram lambs $(42.5 \pm 3.6 \mathrm{~kg}$ of body weight and six months old $)$ were placed in suspended metabolism crates $(1.3 \mathrm{~m}$ $\times 0.55 \mathrm{~m})$ designed to allow the separation and collection of feces and urine. Crates equipped with feeders and water troughs were kept in a shaded barn. Ram lambs were dewormed prior to the onset of the experiment with $5 \mathrm{~mL}$ of $5 \%$ levamisole chloridate and $1 \mathrm{~mL}$ of $1 \%$ moxidectin. All animals also received a supplement injection of vitamins $\mathrm{A}, \mathrm{D}$ and $\mathrm{E}$.

The trial consisted of a 13-d period with 8-d for treatment adaptation and 5-d for feces and urine collection. Animals were assigned to a randomized complete block design with four treatments and six replicates. Blocks were defined by body weight (BW) at the onset of the experiment. Treatments were defined by the replacement of hay (Cynodon sp.) NDF by SH NDF.

Experimental diets were formulated to meet ram lamb requirements recommended by NRC (1985) and provided similar concentrations of NDF (52\%) and crude protein $(\mathrm{CP} ; 15 \%)$. Hay NDF from a $70 \%$ roughage-based diet (SH0) was replaced with SH NDF by $33 \%$ (SH33), 67\% (SH67), and 100\% (SH100), resulting in $0,25,52$, and $77 \%$ of $\mathrm{SH}$ in the dietary DM, respectively. Hay was roughly chopped to reduce animal selection and feed waste. Twenty-five milligrams of monensin (commercial product containing 10\% of active compound) were added per $\mathrm{kg}$ of diet (on asfed basis). The composition of the experimental diets is provided in Table 1.

Diets were daily fed (8:00 am) and ram lambs were allowed ad libitum access to feed and water. Total amount of feed offered to animals was calculated every day to reduce the animal diet selection and feed wastage. Feed and orts were weighed and daily recorded to calculate dry matter intake (DMI). Feed, orts, and feces from each animal were sampled and collected during day 9 to 13 of the experimental period and immediately frozen at $-18^{\circ} \mathrm{C}$.

Animals were weighed without fasting during three consecutive days at the onset and end of the trial to evaluate BW changes. During the collection period, animals were daily offered $8 \mathrm{~L}$ of water. Remaining amount of water was daily recorded. A similar trough used in crates was placed in the experimental barn to evaluate the amount of evaporated water. The evaporated volume was subtracted from water intake.

\section{Chemical analyses}

Samples were thawed and ground with a Wiley mill to pass a 1-mm screen. Fecal samples were dried in a forced-air oven at $55^{\circ} \mathrm{C}$ for $72 \mathrm{~h}$. Feed, orts, and fecal samples were composited for each lamb. Samples were analyzed for DM, organic matter (OM), N 
Table 1 - Composition of experimental diets and chemical analyses of soybean hulls, coastcross hay, and experimental diets fed to Santa Inês ram lambs (\% of DM).

\begin{tabular}{|c|c|c|c|c|c|c|}
\hline \multirow{2}{*}{ Item } & \multirow{2}{*}{ Soybean hulls } & \multirow{2}{*}{ Hay } & \multicolumn{4}{|c|}{ Treatments $^{1}$} \\
\hline & & & SH0 & SH33 & SH67 & SH100 \\
\hline \multicolumn{7}{|l|}{ Ingredients } \\
\hline Coastcross hay, chopped & - & - & 70.30 & 47.10 & 23.20 & - \\
\hline Soybean hulls & - & - & - & 25.40 & 51.60 & 77.00 \\
\hline Ground corn & - & - & 20.90 & 20.31 & 20.30 & 20.87 \\
\hline Soybean meal & - & - & 6.30 & 4.90 & 2.90 & - \\
\hline Urea & - & - & 0.80 & 0.76 & 0.80 & 0.93 \\
\hline Limestone & - & - & 0.50 & 0.33 & - & - \\
\hline Mineral Premix ${ }^{2}$ & - & - & 1.20 & 1.20 & 1.20 & 1.20 \\
\hline \multicolumn{7}{|l|}{ Chemical composition } \\
\hline Dry matter (as-fed basis) & 89.28 & 91.16 & 90.30 & 89.71 & 89.42 & 88.98 \\
\hline Crude Protein & 15.08 & 11.15 & 14.94 & 15.27 & 15.05 & 15.20 \\
\hline Ash & 4.59 & 7.76 & 7.53 & 6.40 & 5.44 & 4.77 \\
\hline $\mathrm{NDF}$ & 64.12 & 73.16 & 51.88 & 53.68 & 51.30 & 52.85 \\
\hline ADF & 50.34 & 36.34 & 24.79 & 30.10 & 35.34 & 39.6 \\
\hline $\mathrm{NDF}_{\text {forage }}{ }^{3}$ & - & - & 51.43 & 34.47 & 16.97 & - \\
\hline $\mathrm{NDF}_{\text {hulls }}{ }^{4}$ & - & - & - & 16.29 & 33.09 & 49.37 \\
\hline $\mathrm{NDF}_{\text {forage }}{ }^{3}(\%$ of total NDF) & - & - & 99.10 & 64.20 & 33.01 & - \\
\hline $\mathrm{NDF}_{\text {hulls }}^{4}(\%$ of total NDF $)$ & - & - & - & 30.35 & 64.50 & 93.42 \\
\hline
\end{tabular}

${ }^{1} \mathrm{SH} 0=$ total inclusion of hay; SH33 = replacement of 33\% of hay NDF by soybean hulls NDF; SH67 = replacement of $67 \%$ of hay NDF by soybean hulls NDF; and SH100 = total replacement of hay NDF by soybean hulls NDF. ${ }^{2}$ Composition:7.5\% P, $13.4 \% \mathrm{Ca}, 1 \% \mathrm{Mg}$, $7 \% \mathrm{~S}, 14.5 \% \mathrm{Na}, 21.8 \% \mathrm{Cl}, 500 \mathrm{mg} \mathrm{kg}^{-1} \mathrm{Fe}, 300 \mathrm{mg} \mathrm{kg}^{-1} \mathrm{Cu}, 4600 \mathrm{mg} \mathrm{kg}^{-1} \mathrm{Zn}, 1100 \mathrm{mg} \mathrm{kg}^{-1} \mathrm{Mn}, 55 \mathrm{mg} \mathrm{kg}^{-1} \mathrm{I}, 40 \mathrm{mg} \mathrm{kg}^{-1} \mathrm{Co}_{\text {, and }} 30 \mathrm{mg}^{\circ}$ $\mathrm{kg}^{-1}$ Se. ${ }^{3}$ Neutral detergent fiber from forage. ${ }^{4}$ Neutral detergent fiber from soybean hulls.

(AOAC, 1990), and NDF according to Van Soest et al. (1991) utilizing $\alpha$-amylase and sodium sulfite. The ADF, not sequential, was determined according to Goering \& Van Soest (1970). The NDF and ADF concentrations were corrected for ash.

Urine samples were individually collected using containers with sufficient volume $(30-60 \mathrm{~mL})$ of $6 \mathrm{~mol} \mathrm{~L}^{-1} \mathrm{HCl}$ to prevent ammonia volatilization, maintaining a $\mathrm{pH}$ bellow 3.0. Urine $\mathrm{pH}$ was measured twice a day. The total volume of urine was daily recorded from days 9 to 13 , subtracting the added volume of acid and correcting the dilution effect caused by $\mathrm{HCl}$ addition. A $10 \%$ aliquot of urine was daily retained and composited for each lamb. Urine samples were stored at $-18^{\circ} \mathrm{C}$. After thawing, urine samples were analyzed for $\mathrm{N}$ using the macro-Kjeldahl technique (AOAC, 1990). Digestibilities and $N$ retention were calculated by difference.

\section{Statistical analyses}

Statistical analyses were performed using the GLM procedure of SAS (1999). Blocks and treatments were used in the model. Treatment means were obtained using the LSMEANS command. Linear, quadratic, and cubic responses were determined using polynomial regression. Significant effects were considered when $p<0.05$. However, $p$-values lower than 0.10 were shown in tables for better interpretation. Simple linear regression was performed for variables of digestibility.

\section{RESULTS AND DISCUSSION}

\section{Nutrient intakes}

The BW, metabolic weight, and nutrient intakes of Santa Inês ram lambs are provided in Table 2. The DMI and organic matter intake (OMI) presented linear increases $(p<0.01)$ with SH addition. The increase in DMI was also observed when SH replaced hay in the diets, with animals consuming 54.6, 67.4, 73.6, and $95.4 \mathrm{~g} \mathrm{DM} \mathrm{kg} \mathrm{BW}^{-0.75}$ for treatments containing $0,30,60$, and $90 \%$ of SH in the dietary DM, respectively (Berge \& Dulphy, 1991). Gomes et al. (2004) and Trater et al. (2001) also showed increases in DMI when SH replaced forage in diets offered to Churra da Terra Quente ewe lambs and Holstein steers, respectively.

The increases in DMI and OMI with $\mathrm{SH}$ inclusion were due to the higher SH digestibility compared to coastcross hay, probably due to the lower in- 
Table 2 - Body weight, metabolic weight and nutrient intakes of Santa Inês ram lambs fed combinations of soybean hulls and coastcross hay.

\begin{tabular}{|c|c|c|c|c|c|c|c|}
\hline \multirow{2}{*}{ Item } & \multicolumn{4}{|c|}{ Treatments $^{1}$} & \multirow{2}{*}{ SEM $^{2}$} & \multicolumn{2}{|c|}{ Effect $^{3}$} \\
\hline & SH0 & SH33 & SH67 & SH100 & & $\mathrm{L}$ & Q \\
\hline Body weight (kg) & 41.03 & 43.36 & 43.13 & 42.4 & - & - & - \\
\hline Metabolic weight $\left(\mathrm{kg} \mathrm{BW}^{0.75}\right)$ & 16.20 & 16.89 & 16.82 & 16.60 & - & - & - \\
\hline \multicolumn{8}{|l|}{ Dry matter intake } \\
\hline$k g$ day $^{-1}$ & 1.05 & 1.35 & 1.34 & 1.43 & 0.07 & $<0.01$ & NS \\
\hline$\%$ of $\mathrm{BW}$ & 2.56 & 3.13 & 3.20 & 3.35 & 0.13 & $<0.01$ & NS \\
\hline $\mathrm{g} \mathrm{kg} \mathrm{BW}^{-0.75}$ & 64.64 & 80.25 & 81.87 & 85.47 & 3.45 & $<0.01$ & NS \\
\hline \multicolumn{8}{|l|}{ Organic matter intake } \\
\hline $\mathrm{kg} \mathrm{day}^{-1}$ & 0.97 & 1.27 & 1.27 & 1.36 & 0.06 & $<0.01$ & NS \\
\hline$\%$ of $\mathrm{BW}$ & 2.36 & 2.94 & 3.03 & 3.20 & 0.12 & $<0.01$ & NS \\
\hline $\mathrm{g} \mathrm{kg} \mathrm{BW}^{-0.75}$ & 59.78 & 75.28 & 77.66 & 81.71 & 3.25 & $<0.01$ & NS \\
\hline \multicolumn{8}{|l|}{ Crude protein intake } \\
\hline $\mathrm{kg} \mathrm{day}{ }^{-1}$ & 0.16 & 0.21 & 0.21 & 0.22 & 0.01 & $<0.01$ & $\mathrm{NS}^{4}$ \\
\hline$\%$ of $\mathrm{BW}$ & 0.39 & 0.48 & 0.48 & 0.50 & 0.02 & $<0.01$ & NS \\
\hline $\mathrm{g} \mathrm{kg} \mathrm{BW}^{-0.75}$ & 9.80 & 12.24 & 12.24 & 12.88 & 0.54 & $<0.01$ & NS \\
\hline \multicolumn{8}{|l|}{ NDF intake } \\
\hline $\mathrm{kg} \mathrm{day}^{-1}$ & 0.53 & 0.73 & 0.71 & 0.77 & 0.34 & $<0.01$ & $\mathrm{NS}^{4}$ \\
\hline$\%$ of $\mathrm{BW}$ & 1.28 & 1.69 & 1.68 & 1.74 & 0.05 & $<0.01$ & $<0.01$ \\
\hline $\mathrm{g} \mathrm{kg} \mathrm{BW}^{-0.75}$ & 32.48 & 43.44 & 43.13 & 46.36 & 1.68 & $<0.01$ & $<0.05$ \\
\hline \multicolumn{8}{|l|}{ ADF intake } \\
\hline $\mathrm{kg} \mathrm{day}^{-1}$ & 0.26 & 0.41 & 0.48 & 0.61 & 0.02 & $<0.01$ & NS \\
\hline$\%$ of $\mathrm{BW}$ & 0.64 & 0.95 & 1.16 & 1.30 & 0.33 & $<0.01$ & $<0.05$ \\
\hline $\mathrm{g} \mathrm{kg} \mathrm{BW}^{-0.75}$ & 16.19 & 24.34 & 29.71 & 34.68 & 1.20 & $<0.01$ & NS \\
\hline
\end{tabular}

${ }^{1} \mathrm{SH} 0=$ total inclusion of hay; SH33 = replacement of 33\% of hay NDF by soybean hulls NDF; SH67 = replacement of $67 \%$ of hay NDF by soybean hulls NDF; and SH100 = total replacement of hay NDF by soybean hulls NDF. ${ }^{2} \mathrm{SEM}=\mathrm{Standard}$ error of the mean. ${ }^{3} \mathrm{~L}=$ Linear effect; $\mathrm{Q}=$ Quadratic effect; NS = Non-significant with $p>0.10$; Cubic effect was non-significant with $p>0.10$ for all variables. The exceptions were NDF intake, expressed as $\%$ of BW and $\mathrm{g} \mathrm{kg} \mathrm{BW}^{-0.75}$, that showed non-significant cubic effects $(p>0.05)$, however $p=0.06$ and $p=0.07$, respectively. ${ }^{4}$ Non-significant $(p>0.05)$, however $p=0.08$.

take of undegradable DM according to SH addition. For high forage diets, the feed accumulation causes an increase in ruminal volume and weight, stimulating stretch receptors in the muscle layer in the wall of reticulum-rumen to signal to brain satiety centers (Allen, 2000). Additionally, the higher ruminal passage rate of SH may be also responsible for the increase in the DMI, since DMI was improved when SH were included in the diet replacing alfalfa haylage, however with no difference in in vitro digestibility of diets (Stone et al., 1993). The high passage rate of SH from the rumen is due to their small particle size (Mertens, 1997) and high specific gravity (Bhatti \& Firkins, 1995).

There was a linear increase $(p<0.01)$ in CP intake with $\mathrm{SH}$ inclusion. This effect is explained by the similar $\mathrm{N}$ content in experimental diets and because DMI increased linearly $(p<0.01)$ with forage replacement by SH. The NDF intakes had quadratic effects when expressed as \% of BW $(p<0.01)$ and $\mathrm{g} \mathrm{kg}$ $\mathrm{BW}^{-0.75}(p<0.05)$, while ADF intakes, when expressed as $\mathrm{kg} \mathrm{day}^{-1}$ and $\mathrm{g} \mathrm{kg} \mathrm{BW}^{-0.75}$, presented linear increases $(p<0.05)$ with $\mathrm{SH}$ addition. This effect is explained because ADF content of SH was higher than ADF content of coastcross hay (Table 1) and it is in agreement with the increase in DMI when forage was replaced by $\mathrm{SH}$.

\section{Nutrient digestibilities}

There was a linear increase $(p<0.01)$ in DM digestibility with $\mathrm{SH}$ addition (Table 3 ). A quadratic effect $(p<0.05)$ was observed for OM digestibility while the same effect showed $p=0.07$ for DM digestibility. A linear increase in total tract DM digestibility was also observed by Grigsby et al. (1992) for beef steers fed SH replacing bromegrass hay. The DM digestibility values were $48.3,51.4,61.2$, and $66.5 \%$ for diets containing $0,15,30$, and $60 \%$ of $\mathrm{SH}$ in the dietary $\mathrm{DM}$, 
respectively. Grigsby et al. (1992) presented higher differences in DM digestibility with SH inclusion when compared with this experiment because the bromegrass hay (5.6\% CP and $87.9 \%$ of cellular wall) had a poorer quality than the coastcross hay used in this experiment.

The increase in DM and OM digestibilities resulted from the higher digestibility of SH compared with coastcross hay. An example of SH DM digestibility is $69.3 \%$ when fed as the only feed to sheep (Hintz et al., 1964), while under Brazilian conditions, value of coastcross hay DM digestibility was $48.1 \%$ for ram lambs weighing $45 \mathrm{~kg}$ of BW (Rocha Júnior et al., 2003).

Apparent DM digestibility did not show a quadratic effect $(p=0.07)$ while the OM digestibility had a quadratic effect $(p<0.05)$. Probably, the current difference was caused by the higher ash content in the coastcross hay than in SH (Table 1). Data of Sudweeks (1977) are in agreement with this experiment, indicating that the DM digestibility was not improved in a diet containing $70 \%$ of SH when compared with a diet containing $40 \%$ of SH.
The regression equations, maximum digestibility values, and $\mathrm{SH}$ levels that maximized digestibility of nutrients are presented in Table 4. Berge \& Dulphy (1991) also verified a quadratic effect in OM digestibility of lambs fed 0 to $90 \%$ of SH in the dietary DM [OM digestibility $=63.9+0.144 \times(\mathrm{SH}$ level in OM basis $)-$ $\left.0.0017 \times(\mathrm{SH} \text { level in OM basis })^{2} ; \mathrm{r}^{2}=0.43\right]$. According to Berge \& Dulphy (1991), the OM digestibility was maximized with $42 \%$ of SH in the dietary OM ( $48 \%$ of SH in dietary DM). In the present experiment, the OM digestibility was maximized with $71 \%$ of $\mathrm{SH}$ in the dietary DM (Table 4). The difference between these values may be attributed to the chemical composition and particle size variations of forage and SH between experiments. The level of DMI and animal variation may be also responsible for differences.

The quadratic effect observed for DM and OM digestibilities was in agreement with Hintz et al. (1964), with a maximization of the DM digestibility when hay replaced $50 \%$ of SH in a diet containing $\mathrm{SH}$ as the sole feed. Hintz et al. (1964) observed a reduction in the total tract passage rate with hay inclusion. A laxative effect of SH was also verified when fed as the sole feed (Quicke et al., 1959). These observations sup-

Table 3 - Apparent digestibility of nutrients according to combinations of soybean hulls and coastcross hay fed to Santa Inês ram lambs.

\begin{tabular}{|c|c|c|c|c|c|c|c|c|}
\hline \multirow{2}{*}{ Digestibility $(\%)^{1}$} & \multicolumn{4}{|c|}{ Treatments $^{2}$} & \multirow{2}{*}{ SEM $^{3}$} & \multicolumn{3}{|c|}{ Effect $^{4}$} \\
\hline & SH0 & SH33 & SH67 & SH100 & & $\mathrm{L}$ & $\mathrm{Q}$ & $\mathrm{C}$ \\
\hline DM & 63.0 & 67.9 & 68.5 & 68.4 & 1.2 & $<0.01$ & $\mathrm{NS}^{5}$ & NS \\
\hline $\mathrm{OM}$ & 64.4 & 69.5 & 69.6 & 69.6 & 1.2 & $<0.01$ & $<0.05$ & NS \\
\hline $\mathrm{CP}$ & 68.5 & 67.3 & 62.9 & 63.2 & 0.6 & $<0.0001$ & NS & $<0.01$ \\
\hline NDF & 60.6 & 68.2 & 66.7 & 66.1 & 1.4 & $\mathrm{NS}^{6}$ & $<0.05$ & NS \\
\hline $\mathrm{ADF}$ & 60.2 & 68.7 & 65.9 & 63.7 & 1.3 & NS & $<0.01$ & NS \\
\hline
\end{tabular}

${ }^{1} \mathrm{DM}=$ Dry matter; $\mathrm{OM}=$ Organic matter; $\mathrm{CP}=$ Crude protein; NDF $=$ Neutral detergent fiber; and ADF $=$ Acid detergent fiber. ${ }^{2} \mathrm{SH} 0$ $=$ total inclusion of hay; SH33 = replacement of 33\% of hay NDF by soybean hulls NDF; SH67 = replacement of $67 \%$ of hay NDF by soybean hulls NDF; and SH100 = total replacement of hay NDF by soybean hulls NDF. ${ }^{3} \mathrm{SEM}=$ Standard error of the mean. ${ }^{4} \mathrm{~L}=\mathrm{Linear}$ effect; $\mathrm{Q}=$ Quadratic effect; $\mathrm{C}=$ Cubic effect; NS = Non-significant with $p>0.10 .{ }^{5}$ Non-significant $(p>0.05)$, however $p=0.07$. ${ }^{6}$ Non-significant $(p>0.05)$, however $p=0.09$.

Table 4 - Regression equations for apparent digestibility according to soybean hulls level in the dietary dry matter fed to Santa Inês ram lambs.

\begin{tabular}{|c|c|c|c|c|}
\hline Digest. ${ }^{1}$ & Equation & $\begin{array}{c}\text { Maximum } \\
\text { Digest. }^{2}\end{array}$ & $\begin{array}{c}\text { Level to } \\
\text { max. }^{3}\end{array}$ & $\mathrm{r}^{2^{*}}$ \\
\hline$\%$ & & $-\ldots-1$ & $-\ldots-1-1$ & \\
\hline $\mathrm{DM}$ & $63.2058+0.1611 *$ level $-0.001112 *$ level $^{2}$ & 69.04 & 72 & 0.35 \\
\hline $\mathrm{OM}$ & $64.5949+0.1635 *$ level $-0.001157 *$ level $^{2}$ & 70.37 & 71 & 0.35 \\
\hline $\mathrm{CP}$ & $68.7231-0.06369 *$ level & 68.72 & 0 & 0.35 \\
\hline NDF & $60.8375+0.2376 *$ level $-0.001904 *$ level $^{2}$ & 68.25 & 62 & 0.30 \\
\hline $\mathrm{ADF}$ & $58.9500+0.3090 *$ level $-0.002707 *$ level $^{2}$ & 67.77 & 57 & 0.46 \\
\hline
\end{tabular}

${ }^{1}$ Digest. = Apparent digestibility of nutrients; $\mathrm{DM}=$ Dry matter; $\mathrm{OM}=$ Organic matter; $\mathrm{CP}=\mathrm{Crude}$ protein; $\mathrm{NDF}=\mathrm{Neutral}$ detergent fiber; and ADF = Acid detergent fiber. ${ }^{2}$ Maximum digest: Maximum digestibility. ${ }^{3}$ Level to max. $(\%)=$ Level of soybean hulls in dietary dry matter that maximized digestibility value. ${ }^{*} \mathrm{r}^{2}=$ Significant $p$ value $(p<0.05)$. 
port the idea that hay addition in a diet containing high amounts of SH reduces the SH passage rate and maximizes their digestion.

There was a cubic decrease in $\mathrm{CP}$ digestibility $(p<0.01)$ with $\mathrm{SH}$ inclusion. In vivo $\mathrm{CP}$ digestibility coefficients of pure $\mathrm{SH}$ are $53.5 \%$ in bovines and $50.8 \%$ in sheep (Hintz et al., 1964), while examples of $\mathrm{CP}$ digestibility coefficients of coastcross hay are $66.96 \%$ and $68.35 \%$ in sheep (Rocha Júnior et al., 2003). Decreases in CP digestibility with SH addition were also observed by Sudweeks (1977), Berge \& Dulphy (1991), and Grigsby et al. (1992). As a result, in this experiment, the cubic decrease in $\mathrm{CP}$ digestibility with SH inclusion may be attributed to the lower $\mathrm{CP}$ digestibility of $\mathrm{SH}$ when compared with coastcross hay. The reduction in the soybean meal level with $\mathrm{SH}$ inclusion may be also partially responsible for the $\mathrm{CP}$ digestibility reduction. The apparent digestibility of $\mathrm{CP}$ fraction must be carefully interpreted due to contamination with microbial protein and endogenous non-dietary waste products.

There was a quadratic increase for NDF $(p<$ $0.05)$ and $\mathrm{ADF}(p<0.01)$ digestibilities with $\mathrm{SH}$ inclusion in the diet. Examples of NDF digestibilities in sheep were $71.8 \%$ for $\mathrm{SH}$, and 50.45 or $55.45 \%$ for coastcross hay (Rocha Júnior et al., 2003). Thus, the inclusion of SH enhanced the NDF digestibility and it was maximized with $68.25 \%$ of SH in the dietary DM.

The decrease in the digestibility of fiber fractions when high amounts of SH were added can be explained by the reduction of ruminal mat formed by the long particles of hay which maximizes the SH ruminal retention time and the extension of SH degradation. Using the Welch device, Weidner \& Grant (1994b) and Mulligan et al. (2002) observed the lower ruminal mat consistency of diets with high amounts of SH when compared with high forage diets. As a result, the high ruminal passage rate of $\mathrm{SH}$ is the major factor explaining the low digestibility of $\mathrm{SH}$ fiber (Grant, 1997).

Ruminal pH of 6.1 was observed when lambs were fed a diet containing $90 \%$ of SH in the dietary DM (Berge \& Dulphy, 1991). Additionally, ruminal pH of 5.36 was reported in sheep when $80 \%$ of SH were included in the dietary DM (Hsu et al., 1987). A ruminal pH of 6.2 (Hoover, 1986) or 6.0 (Ørskov, 1982) is sufficient to reduce fiber degradation. Therefore, the low ruminal $\mathrm{pH}$ could be a reason for the reduction in fiber digestibility observed in this experiment when high levels of SH were included. Unfortunately, $\mathrm{pH}$ and other ruminal parameters were not measured in this trial because animal were not cannulated.

Cellulose in vitro digestibility ranging from 60 to $80 \%$ was found in the feces of sheep fed $\mathrm{SH}$ as the only feed, while in vitro digestibility of cellulose in the feces ranged from 0 to $20 \%$ when sheep were fed different forage sources (Johnson et al., 1959). Concluding, these observations agree with the rapid escape of SH from the rumen and with the low $\mathrm{pH}$ theories.

\section{Nitrogen balance}

There was a linear increase $(p<0.01$; Table $5)$ in $\mathrm{N}$ intake $\left(\mathrm{g} \mathrm{day}^{-1}\right)$ with $\mathrm{SH}$ inclusion. Treatment diets contained similar $\mathrm{N}$ concentrations, consequently the linear increase in $\mathrm{N}$ intake is attributed to the linear increase in DMI observed with the replacement of hay by SH. Similar effects were observed when concentrate replaced forage in Santa Inês diets (Silva et al., 2004). On the other hand, there was no increase in $\mathrm{N}$ intake for diets containing similar $\mathrm{N}$ concentrations when the forage level was $0,10,20$, and $30 \%$ of dietary DM (Fimbres et al., 2002).

Fecal $\mathrm{N}\left(\mathrm{g} \mathrm{day}^{-1}\right)$ also increased linearly $(p<0.01)$ with SH inclusion. The higher amount of $\mathrm{N}$ in feces was due to the higher DMI and the reduction in CP digestibility with $\mathrm{SH}$ addition. Urinary $\mathrm{N}\left(\mathrm{g} \mathrm{day}^{-1}\right)$ was not affected $(p>0.10)$ by SH inclusion. A quadratic effect $(p<0.05)$ was observed in $\mathrm{N}$ retention when expressed as \% of $\mathrm{N}$ intake and $\%$ of $\mathrm{N}$ absorbed. The reduction in $\mathrm{N}$ retention started with $25 \%$ of SH in the dietary DM (treatment SH33). Drastic reduction was verified only when $77 \%$ of SH were added in the dietary DM (treatment SH100). The reduction in $\mathrm{N}$ retention is a direct effect of the decrease in $\mathrm{CP}$ digestibility with $\mathrm{SH}$ addition.

\section{Water intake}

There was no effect ( $p>0.05$; Table 6) of SH inclusion on water intake for all units. However, water intake showed $p=0.07$ when expressed as $\mathrm{L}$ of water $\mathrm{kg}^{-1} \mathrm{DM}$ ingested. A speculation is that forages have a higher water holding capacity when compared with SH (Bhatti \& Firkins, 1995). Thus, to maintain the ruminal fluidity, ram lambs fed high amounts of hay needed to consume more water compared to ram lambs fed high amounts of $\mathrm{SH}$.

Dorper lambs presented a water intake of $246.1 \mathrm{~mL} \mathrm{~kg} \mathrm{BW}^{-0.75}$ (Schoeman \& Visser, 1995) and Merino lambs a water intake of $301.5 \mathrm{~mL} \mathrm{~kg} \mathrm{BW}^{-0.75}$ (Ferreira et al., 2002). Lower values are presented in this experiment with an average of $197 \mathrm{~mL} \mathrm{~kg} \mathrm{BW}^{-0.75}$. Despite environmental effects, the lower mean value for Santa Inês compared to Merino and Dorper may be may be related to the adaptation of Santa Inês to the drought conditions of the Brazilian Semi-Arid, showing putative higher water conservation effi- 
Table 5 - Nitrogen intake and $\mathrm{N}$ balance of Santa Inês ram lambs fed combinations of soybean hulls and coastcross hay.

\begin{tabular}{|c|c|c|c|c|c|c|c|}
\hline \multirow{2}{*}{ Item } & \multicolumn{4}{|c|}{ Treatments $^{1}$} & \multirow{2}{*}{$\mathrm{SEM}^{2}$} & \multicolumn{2}{|c|}{ Effect $^{3}$} \\
\hline & SH0 & SH33 & SH67 & SH100 & & $\mathrm{L}$ & Q \\
\hline $\mathrm{N}$ intake $\left(\mathrm{g} \mathrm{day}^{-1}\right)$ & 25.44 & 33.62 & 32.91 & 34.40 & 1.85 & $<0.01$ & NS \\
\hline Fecal N $\left(\mathrm{g} \mathrm{day}^{-1}\right)$ & 8.17 & 10.81 & 12.20 & 12.62 & 0.63 & $<0.01$ & NS \\
\hline Urinary $\mathrm{N}\left(\mathrm{g} \mathrm{day}^{-1}\right)$ & 9.40 & 9.07 & 8.74 & 9.15 & 0.64 & NS & NS \\
\hline \multicolumn{8}{|l|}{$\mathbf{N}$ retention } \\
\hline g day ${ }^{-1}$ & 7.87 & 13.11 & 11.97 & 12.17 & 1.21 & $<0.05$ & $\mathrm{NS}^{4}$ \\
\hline$\%$ of $\mathrm{N}$ intake & 30.91 & 39.48 & 36.40 & 34.93 & 2.24 & NS & $<0.05$ \\
\hline$\%$ of $\mathrm{N}$ absorbed & 44.37 & 58.59 & 58.10 & 55.23 & 3.57 & $\mathrm{NS}^{5}$ & $<0.05$ \\
\hline
\end{tabular}

${ }^{1} \mathrm{SH0}=$ total inclusion of hay; SH33 = replacement of 33\% of hay NDF by soybean hulls NDF; SH67 = replacement of $67 \%$ of hay NDF by soybean hulls NDF; and SH100 = total replacement of hay NDF by soybean hulls NDF. ${ }^{2} \mathrm{SEM}=\mathrm{Standard}$ error of the mean. ${ }^{3} \mathrm{~L}=$ Linear effect; $\mathrm{Q}=$ Quadratic effect; NS = Non-significant with $p>0.10$; Cubic effect was non-significant with $p>0.10$ for all variables. ${ }^{4}$ Non-significant $(p>0.05)$, however $p=0.06$. ${ }^{5}$ Non-significant $(p>0.05)$, however $p=0.09$.

Table 6 - Water intake of Santa Inês ram lambs fed combinations of soybean hulls and coastcross hay.

\begin{tabular}{|c|c|c|c|c|c|c|c|}
\hline \multirow{2}{*}{ Water intake ${ }^{1}$} & \multicolumn{4}{|c|}{ Treatments $^{2}$} & \multirow{2}{*}{$\mathrm{SEM}^{3}$} & \multicolumn{2}{|c|}{ Effect $^{4}$} \\
\hline & SH0 & SH33 & SH67 & SH100 & & $\mathrm{L}$ & Q \\
\hline $\mathrm{L} \mathrm{day}^{-1}$ & 3.13 & 3.51 & 3.21 & 3.58 & 0.30 & NS & NS \\
\hline 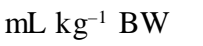 & 75.50 & 80.50 & 67.25 & 84.00 & 5.97 & NS & NS \\
\hline $\mathrm{mL} \mathrm{kg} \mathrm{BW}^{-0.75}$ & 191.50 & 206.70 & 171.80 & 214.80 & 15.43 & NS & NS \\
\hline $\mathrm{L} \mathrm{kg}^{-1} \mathrm{DMI}$ & 2.97 & 2.61 & 2.36 & 2.33 & 0.23 & $\mathrm{NS}^{5}$ & NS \\
\hline
\end{tabular}

${ }^{1} \mathrm{BW}=$ Body weight; and DMI = Dry matter intake. ${ }^{2} \mathrm{SHO}=$ total inclusion of hay; $\mathrm{SH} 33=$ replacement of $33 \%$ of hay NDF by soybean hulls NDF; SH67 = replacement of $67 \%$ of hay NDF by soybean hulls NDF; and SH100 = total replacement of hay NDF by soybean hulls NDF. ${ }^{3} \mathrm{SEM}=$ Standard error of the mean. ${ }^{4} \mathrm{~L}=$ Linear effect; $\mathrm{Q}=$ Quadratic effect; NS = Non-significant with $p>0.10$; Cubic effect was non-significant with $p>0.10$ for all variables. ${ }^{5}$ Non-significant $(p>0.05)$, however $p=0.07$.

ciency. It is an interesting field of study and experiments should be designed to support this hypothesis or not.

\section{CONCLUSION}

The inclusion of soybean hulls increased dry matter intake and also dry matter and organic matter digestibilities. However, the inclusion of long particle forage is necessary to maximize nutrient digestibilities. Crude protein digestibility reduced when soybean hulls were included, affecting the nitrogen balance and increasing the output of fecal N. Soybean hulls can replace forage for ram lamb diets and may be used up to $77 \%$ in the dietary DM with satisfactory values of nutrient digestibilities.

\section{ACKNOWLEDGEMENTS}

To FAPESP (The State of São Paulo Research Foundation) for financial support (Proj. 04/04771-2) and for the first author's scholarship (Proj. 04/047706). Authors wish to express their gratitude to Bunge Alimentos S.A. for soybean hulls supply.

\section{REFERENCES}

ALLEN, M.S. Effects of diet on short-term regulation of feed intake by lactating dairy cows. Journal of Dairy Science, v.83, p.1598-1624, 2000.

ASSOCIATION OF OFFICIAL ANALYTICAL CHEMISTS. Official methods of analysis. $15 \mathrm{ed}$. Arlington: AOAC, 1990. v.1, 1117p.

BERGE, P.; DULPHY, J.P. Étude des interactions entre fourrage et aliment concentré chez le mouton. II. Facteurs de variation de la digestibilité. Annales de Zootechnie, v.40, p.227-246, 1991.

BHATTI, S.A.; FIRKINS, J.L. Kinetics of hydration and functional specific gravity of fibrous feed by-products. Journal of Animal Science, v.73, p.1449-1458, 1995.

FERREIRA, A.V.; HOFFMAN, L.C.; SCHOEMAN, S.J.; SHERIDAN, R. Water intake of Boer goats and Mutton merinos receiving either a low or high energy feedlot diet. Small Ruminant Research, v.43, p.245-248, 2002.

FIGUEIREDO, E.A.P.; SHELTON, M.; BARBIERI, M.E. Available genetic resources: the origin and classification of the world's sheep. In: SHELTON, M.; FIGUEIREDO, E.A.P. (Ed.) Hair sheep production in tropical and sub-tropical regions: with reference to Northeast Brazil and the countries of the Caribbean, Central America, and South America. Davis: University of California, 1990. chapter 2, p.7-23.

FIMBRES, H.; KAWAS, J.R.; HERNÁNDEZ-VIDAL, G.; PICÓNRUBIO, J.F.; LU, C.D. Nutrient intake, digestibility, mastication and ruminal fermentation of lambs fed finishing ration with various forage levels. Small Ruminant Research, v.43, p.275-281, 2002. 
GOERING, H.K.; Van SOEST, P.J. Forage fiber analysis: apparatus, reagents, procedures and some applications. Washington, D.C.: Agricultural Research Service, 1970. 19p. (Agricultural Handbook, 379).

GOMES, M.J.; DIAS-DA-SILVA, A.A.; AZEVEDO, J.M.T.; GUEDES, C.M. Response of lambs fed wheat straw-based diets to supplementation with soybean hulls. Australian Journal of Agricultural Research, v.55, p.261-272, 2004.

GRANT, R.J. Interactions among forages and nonforage fiber sources. Journal of Dairy Science, v.80, p.1438-1446, 1997.

GRIGSBY, K.N.; KERLEY, M.S.; PATERSON, J.A.; WEIGEL, J.C. Site and extent of nutrient digestion by steers fed a low-quality bromegrass hay diet with incremental levels of soybean hull substitution. Journal of Animal Science, v.70, p.1941-1949, 1992.

HALL, M.B.; PELL, A.N.; CHASE, L.E. Characteristics of neutral detergent-soluble fiber fermentation by mixed ruminal microbes. Animal Feed Science and Technology, v.70, p.23-39, 1998.

HINTZ, H.F.; MATHIAS, M.M.; LEY-JUNIOR, H.F.; LOOSLI, J.K. Effects of processing and of feeding hay on the digestibility of soybean hulls. Journal of Animal Science, v.23, p.43-46, 1964.

HOOVER, W.H. Chemical factors involved in ruminal fiber digestion. Journal of Dairy Science, v.69, p.2755-2766, 1986.

HSU, J.T.; FAULKNER, D.B.; GARLEB, K.A.; BARCLAY, R.A.; FAHEY-JUNIOR, G.C.; BERGER, L.L. Evaluation of corn fiber, cottonseed hulls, oat hulls and soybean hulls as roughage sources for ruminants. Journal of Animal Science, v.65, p.244-255, 1987.

JOHNSON, R.R.; SCOTT, H.W.; MOXON, A.L.; BENTLEY, O.G. The digestible cellulose remaining in the feces of sheep fed different roughages as determined by in vitro rumen fermentation. Journal of Animal Science, v.18, p.1520, 1959.

MERTENS, D.R. Creating a system for meeting the fiber requirements of dairy cows. Journal of Dairy Science, v. 80 , p.1463-1481, 1997

MIRON, J.; YOSEF, E.; BEN-GHEDALIA, D. Composition and in vitro digestibility of monosaccharide constituents of selected byproducts feeds. Journal of Agricultural Food and Chemistry, v.49, p.2322-2326, 2001

MULLIGAN, F.J.; CAFFREY, P.J.; RATH, M.; CALLAN, J.J.; BROPHY, P.O.; O'MARA, F.P. An investigation of feeding level effects on digestibility in cattle for diets based on grass silage and high fibre concentrates at two forage:concentrate ratios. Livestock Production Science, v.77, p.311-323, 2002.

NAKAMURA, T.; OWEN, F.G. High amounts of soyhulls for pelleted concentrate diets. Journal of Dairy Science, v.72, p.988-994, 1989.

NATIONAL RESEARCH COUNCIL. Nutrient requirements of dairy cattle. 7 ed. Washington, D.C.: National Academic Press, 2001. 381p.

NATIONAL RESEARCH COUNCIL. Nutrient requirements of sheep. 6 ed. Washington, D.C.: National Academic Press, 1985. $99 \mathrm{p}$.

ØRSKOV, E.R. Protein nutrition in ruminants. London: Academic Press, 1982. 175p.
QUICKE, G.V.; BENTLEY, O.G.; SCOTT, H.W.; JOHNSON, R.R.; MOXON, A.L. Digestibility of soybean hulls and flakes and the in vitro digestibility of the cellulose in various milling byproducts. Journal of Animal Science, v.42, p.185-186, 1959.

ROCHA, M.H.; SUSIN, I.; PIRES, A.V.; FERNANDES-JUNIOR, J.S.; MENDES, C.Q. Performance of Santa Ines lambs fed diets of variable crude protein levels. Scientia Agricola, v.61, p.141$145,2004$.

ROCHA JÚNIOR, V.R.R.; VALADARES FILHO, S.C.; BORGES, A.M.; MAGALHÃES, K.A.; FERREIRA, C.C.B.; VALADARES, R.F.D.; PAULINO, M.F. Determinação do valor energético de alimentos para ruminantes pelo sistema de equações. Revista Brasileira de Zootecnia, v.32, p.473-479, 2003.

SAS INSTITUTE. SAS systems for windows: version 8.2. Cary: SAS Institute, 1999.

SCHOEMAN, S.J.; VISSER, J.A. Water intake and consumption in sheep differing in growth potential and adaptability. South African Journal of Animal Science, v.25, p.75-79, 1995.

SILVA, A.M.A.; SILVA SOBRINHO, A.G.; TRINDADE, I.A.C.M.; RESENDE, K.T.; BAKKE, O.A. Food intake and digestive efficiency in temperate wool and tropic semi-arid hair lambs fed different concentrate:forage ratio diets. Small Ruminant Research, v.55, p.107-155, 2004.

STONE, W.C.; CHASE, L.E.; PELL, A.N.; GROHN, Y.T. The effectiveness of soyhulls as a roughage or concentrate replacement in early lactation Holstein dairy cows. Journal of Dairy Science, v.76 (Suppl 1), p.211, 1993.

SUDWEEKS, E.M. Digestibility by sheep of diets of citrus pulp, corn, or soybean mill feed with three forages. Journal of Dairy Science, v.60, p.1410-1415, 1977.

TRATER, A.M.; TITGEMEYER, E.C.; LÖEST, C.A.; LAMBERT, B.D. Effects of supplemental alfalfa hay on the digestion of soybean hull-based diets by cattle. Journal of Animal Science, v.79, p.1346-1351, 2001.

URANO, F.S.; PIRES, A.V.; SUSIN, I.; MENDES, C.Q.; RODRIGUES, G.H.; ARAUJO, R.C.; MATTOS, W.R.S. Desempenho e características da carcaça de cordeiros confinados alimentados com grão de soja. Pesquisa Agropecuária Brasileira, v.41, p.1525-1530, 2006.

Van SOEST, P.J. van; ROBERTSON, J.B.; LEWIS, B.A. Methods for dietary fiber, neutral detergent fiber, and nonstarch polysaccharides in relation to animal nutrition. Journal of Dairy Science, v.74, p.3583-3597, 1991.

WEIDNER, S.J.; GRANT, R.J. Soyhulls as a replacement for forage fiber in diets for lactating dairy cows. Journal of Dairy Science, v.77, p.513-521, 1994a.

WEIDNER, S.J.; GRANT, R.J. Altered ruminal mat consistency by high percentages of soybean hulls fed to lactating dairy cows. Journal of Dairy Science, v.77, p.522-532, 1994 b.

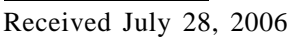

Accepted June 20, 2008 